Journal of Applied Veterinary Sciences, 6 (2): 92 - 97 (April, 2021).

ISSN: Online: 2090-3308, Print: 1687-4072

Journal homepage : https://javs.journals.ekb.eg

\title{
Detection of Aflatoxigenic Fungi in Poultry Feed
}

\author{
Walid H. Hassan ${ }^{1}$, Salem R. Mostafa ${ }^{2}$, Hossam A. Khalil ${ }^{2 *}$ and Ahmed H. Abed ${ }^{1}$ \\ ${ }^{1}$ Bacteriology, Mycology and Immunology Department, Faculty of Veterinary Medicine, Beni-Suef University, Egypt. \\ ${ }^{2}$ Microbiology Department, Animal Health Research Institute, Beni-Suef, Egypt. \\ *Corresponding Author, Hossam A. Khalil, E-Mail: dr.hossamali2017@gmail.com
}

\begin{abstract}
Mycotoxins are poisonous biomolecules produced as secondary metabolites by some fungal species, as they grow on various substrates under suitable growth conditions. Approximately, 83\% of these deaths occur in East Asia and sub-Saharan Africa. It has been estimated that more than five billion people in developing countries are at risk of chronic exposure to aflatoxins, through contaminated foods/feeds Several studies revealed that $\mathrm{A}$. flavus and $\mathrm{A}$. parasiticus are of significant concern in poultry contamination, being the most common producers of aflatoxins. In the current study, a total of 120 samples of poultry feeds were collected from different localities of Beni-Suef Governorate. The samples were examined for the existence of Aspergillus species. Moreover, the capacity to produce aflatoxins by the Aspergillus flavus was determined. The results revealed that the most predominant Aspergillus isolates was A. flavus ( $n=$ $75 ; 62.5 \%)$ followed by $A$. niger $(n=31 ; 25.9 \%)$ and A. fumigatus $(n=19$; $15.8 \%)$. Out of 75 A. flavus isolates, 43 strains (57.3\%) produced aflatoxins. These results concluded the potential exists for the production of mycotoxins by the Aspergillus flavus. The present study was designed to investigate the existence of Aspergillus species in poultry feed as well as determining the capacity of Aspergillus flavus isolates to produce aflatoxins.
\end{abstract}

Original Article:

DOI:https://dx.doi.org/10.21608/javs .2021.68213.1074

Received :17 March, 2021.

Accepted:23 April,2021.

Published in April, 2021.

This is an open access article under the term of the Creative Commons Attribution 4.0 (CC BY) International License. To view a copy of this license, visit:

http://creativecommons.org/licenses/by/4.0/

Keywords: Aflatoxin, Aspergillus flavus, biomolecules, poultry feed. $\quad$ J. Appl. Vet. Sci., 6(2 ): 92- 97.

\section{INTRODUCTION}

Mycotoxins are poisonous biomolecules that are produced as secondary metabolites by some fungal species, as they grow on various substrates under suitable growth conditions (Tola and Kebede, 2016).

Several mold fungi are capable of contaminating various foods and feed with these toxic secondary metabolites, which have adverse effects on human and animal consumers following consumption of these contaminated food or animal feed (WHO, 2006; Maciorowski et al., 2007; Mostafa et al., 2012).

Moreover, Liu and Wu, (2010); Salim et al., (2011) added that the mycotoxins are responsible for many acute and chronic diseases in humans and animals such as; liver damage, esophageal cancer, reduced digestive enzyme activity, immune suppression, and various effects on children including stunted growth with many annual mortality cases. In addition to causing diseases, mycotoxigenic fungi and mycotoxins affect feed quality by reducing their nutritive value and producing an unpleasant smell.
They also affect poultry performance and health, leading to severe economic losses (Monson et al., 2014).

Several studies revealed that $A$. flavus and $A$. parasiticus are of significant concern in poultry contamination, being the most common producers of aflatoxins (Magnoli et al., 2011; Ghadeer and Al Delamiy, 2012). Among Aspergillus spp., A. flavus was frequently found in contaminated feeds (Varga $\boldsymbol{e t}$ al., 2011).

Generally, aflatoxins are the most common and most toxic primary mycotoxins of concern in poultry feedstuffs. Aflatoxins are composed of several types such as; Aflatoxin B1 (AFB1), Aflatoxin B2 (AFB2), Aflatoxin G1 (AFG1), and Aflatoxin G2 (AFG2). Which are the most commonly encountered (Monbaliu et al., 2010; Lereau et al., 2012). Of these aflatoxins, AFB1 is the most toxic type of aflatoxins and is the most commonly encountered natural carcinogens produced by these Aspergilli (Habib et al., 2015; Haruna et al., 2017). 
Mycotoxins metabolized in the body into its hydroxylated form called Aflatoxin M1 (AFM1), which is excreted in the breast milk of humans and animals following the ingestion of contaminated food or feed with AFB1. (Xu et al., 2000). The most chronic form of aflatoxin exposure manifestation is hepatocellular carcinoma (HCC, or liver cancer), which has been described by WHO as the third-leading cause of cancer death globally (WHO, 2008), and with about 550,000 to 600,000 reported new cases annually (Habib et al., 2015). Approximately, 83\% of these deaths occur in East Asia and sub-Saharan Africa. It has been estimated that more than five billion people in developing countries are at risk of chronic exposure to aflatoxins, through contaminated foods/feeds (Habib $\boldsymbol{e t}$ al., 2015).

The present study was designed to investigate the existence of Aspergillus species in poultry feed as well as determining the capacity of Aspergillus flavus isolates to produce aflatoxins.

\section{MATERIIALS AND METHODS}

\section{Samples:}

A total of 120 samples of poultry feeds ( 90 Poultry ration, 10 Ration concentrates, 10 Yellow corn and 10 Soya bean) were collected from different farms in Beni-Suef Governorate that had a health problem in their flock. The samples were obtained from the feed at the time of the problem. The samples were representative of a lot of feed and included feed from the trough. The samples were examined for fungal contamination and toxin production.

\section{Fungal Isolation:}

The dilution of samples was carried out according to Dalcero et al., (1998). Approximately $10 \mathrm{~g}$ of each sample were diluted in $90 \mathrm{ml}$ sterile distilled water, serial dilutions were done which $1 \mathrm{ml}$ was transferred to a tube containing $9 \mathrm{ml}$ sterile distilled water (10-fold serial dilutions). The tube was shaken and one $\mathrm{ml}$ was removed to a second tube till the $4^{\text {th }}$ dilution $\left(10^{-4}\right)$. Then $0.1 \mathrm{ml}$ is removed from each dilution into a sterile petri dish containing Sabouraud dextrose agar (SDA) with chloramphenicol $(0.05 \mathrm{~g} / \mathrm{l})$ using spread method and incubated at $25-28^{\circ} \mathrm{C}$ for $7-10$ days, all process was done under complete aseptic condition. After incubation, the plates examined visually and microscopically by making films. Individual suspected colonies were selected depending up on their morphological characters. Stock cultures were made from each isolate and maintained in SDA slopes in refrigerator for further identification.

\section{Identification of fungal isolates:}

The recovered Fungal mycelia were identified morphologically according to Rippon (1988) by examination of mycelial morphology, the reverse colour as well as the examination of colonial smears using lactophenol cotton blue stain.

\section{Polymerase Chain Reaction:}

All A. flavus isolates were confirmed by PCR examination using oligonucleotide primers that amplify a $357 \mathrm{bp}$ fragment in Aspergillus $18 S$ rRNA gene of A. flavus (Yamakami et al., 1996)

Primers: (Biobasic Canada)

$\sim$ Primer 1 (Forward primer): 5'- CGGCCCTTAAATAGCCCGGTC- 3'

$\sim$ Primer 2 (Reverse primer):

\section{5'- CCTGAGCCAGTCCGAAGGCC- 3'}

The reaction was performed in a volume of 25 $\mu \mathrm{l}$ consisting of $12.5 \mu \mathrm{l}$ of 10X PCR master mix, $1 \mu \mathrm{l}$ of each 20 pmol primers, $5 \mu$ of DNA extract, and the volume was completed to $25 \mu$ l using sterile deionized water. The thermal profile consisted of primary denaturation at $94^{\circ} \mathrm{C}$ for 5 min., 35 cycles of amplification; denaturation at $94^{\circ} \mathrm{C}$ for 30 sec., primer annealing at $50^{\circ} \mathrm{C}$ for $40 \mathrm{sec}$., and extension at $72^{\circ} \mathrm{C}$ for $40 \mathrm{sec}$. followed by a final extension step at $72^{\circ} \mathrm{C}$ for 10 min. PCR products were visualized using $1 \%$ agarose stained with ethidium bromide using a UV transilluminator.

\section{Methods of DNA Extraction: Extraction of DNA:} instructions

According to QIAamp DNeasy Plant Mini kit

1. $100 \mathrm{mg}$ of the tissue were frozen in $-80^{\circ} \mathrm{C}$ for $24 \mathrm{hrs}$ for later processing. .

2. Fungal material and a tungsten carbide bead were added to a $2 \mathrm{ml}$ safe-lock tube. $400 \mu \mathrm{l}$ Buffer AP1 and $4 \mu \mathrm{l}$ RNase A stock solution $(100 \mathrm{mg} / \mathrm{ml})$ were added. Tubes were placed into the adaptor sets, which are fixed into the clamps of the TissueLyser. Disruption was performed in two 1-2 minute high-speed (20-30 $\mathrm{Hz}$ ) shaking steps.

3. The mixture was incubated for $10 \mathrm{~min}$ at $65^{\circ} \mathrm{C}$ and mixed 2 or 3 times during incubation by

inverting tube.

4. $130 \mu 1 \quad$ Buffer P3 was added to the to the lysate, mixed, and incubated for $5 \mathrm{~min}$ on ice.

5. The lysate was centrifugated for $5 \mathrm{~min}$ at 14,000 rpm.

6. The lysate was pipetted into the QIAshredder Mini spin column (lilac) placed in a $2 \mathrm{ml}$ collection tube, and centrifugated for $2 \mathrm{~min}$ at $14,000 \mathrm{rpm}$.

7. The flow-through fraction from step 16 was transferred into a new tube without disturbing the celldebris pellet.

8. 1.5 volumes of Buffer AW1 was added to the cleared lysate, and mixed by pipetting.

9. $650 \mu \mathrm{l}$ of the mixture from step 8 (including any precipitate that was Formed) were pipetted into the DNeasy Mini spin column placed in a $2 \mathrm{ml}$ collection 
tube and centrifugated for $1 \mathrm{~min} 8000 \mathrm{rpm}$ and the flow-through was discarded.

10. Step 9 was repeated with the remaining sample. The flow-through and collection tube were discarded.

11. The DNeasy Mini spin column was placed into a new $2 \mathrm{ml}$ collection tube.

$500 \mu \mathrm{l}$ Buffer AW2 was added and centrifugated for 1 min at $8000 \mathrm{rpm}$ and the flow-through was discarded.

12. $500 \mu \mathrm{l}$ Buffer AW2 was added to the DNeasy Mini spin column, and centrifugated for $2 \mathrm{~min}$ at $14,000 \mathrm{rpm}$ to dry the membrane.

13. The DNeasy Mini spin column was transferred to a $1.5 \mathrm{ml}$ or $2 \mathrm{ml}$ microcentrifuge tube, and $50 \mu \mathrm{l}$ Buffer $\mathrm{AE}$ were directly pipette onto the DNeasy membrane. It was incubated for $5 \mathrm{~min}$ at room temperature (15$25^{\circ} \mathrm{C}$ ), and then centrifugated for $1 \mathrm{~min}$ at $8000 \mathrm{rpm}$ to elute.

\section{Preparation of PCR Master Mix:}

According to Emerald Amp GT PCR mastermix (Takara) Code No. RR310A kit as shown in table (1):

Table 1: Preparation of PCR Master Mix:

\begin{tabular}{|c|c|}
\hline Component & Volume/reaction \\
\hline $\begin{array}{c}\text { Emerald Amp GT PCR } \\
\text { mastermix (2x premix) }\end{array}$ & $12.5 \mu \mathrm{l}$ \\
\hline PCR grade water & $5.5 \mu \mathrm{l}$ \\
\hline Forward primer (20 pmol) & $1.0 \mu \mathrm{l}$ \\
\hline Reverse primer (20 pmol) & $1.0 \mu \mathrm{l}$ \\
\hline Template DNA & $5.0 \mu \mathrm{l}$ \\
\hline Total & $25 \mu \mathrm{l}$ \\
\hline
\end{tabular}

\section{Cycling conditions of the primers during CPCR:}

Temperature and time conditions of the two primers during PCR are shown in Table (2) according to specific authors and Emerald Amp GT PCR mastermix (Takara) kit.

Table 2: Cycling conditions of the different primers during cPCR

\begin{tabular}{|c|c|c|c|c|c|c|}
\hline 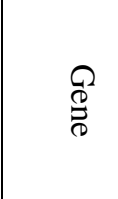 & 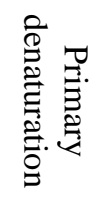 & 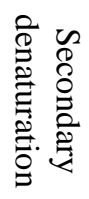 & 节 & $\begin{array}{l}\frac{\pi}{x} \\
\overrightarrow{0} \\
0 \\
0 \\
0 \\
0\end{array}$ & $\begin{array}{l}z \\
0 \\
0 \\
0 \\
2 \\
\vdots \\
0 \\
0\end{array}$ & 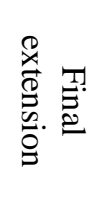 \\
\hline 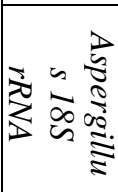 & $\stackrel{u}{u} \stackrel{\circ}{\stackrel{5}{\circ}}$ & 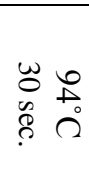 & 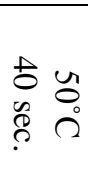 & 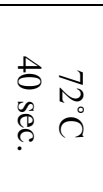 & 35 & $\begin{array}{l}\overrightarrow{0} \\
\vec{E} \\
\vec{E} \cdot \stackrel{N}{0}\end{array}$ \\
\hline
\end{tabular}

\section{Measuring of Aflatoxin by using Fluorometer (Afla Test):}

Aflatoxin was extracted, column chromatographed, and measured by using VICAM series-4 and 4ex All required kits were obtained from VICAM (Milford, MA , USA) according to AOAC (1990).

\section{RESULTS}

Incidence of fungi isolated from the examined samples other than Aspergillus spp.:

Mycological examination of 120 samples of poultry feed showed the presence of 2 genera of fungi (Table 3) other than Aspergillus spp. The two species were Penicillium spp. $(n=37 ; 30.8 \%)$ and Mucor $(n=23 ; 28.3 \%)$.

Table 3: Different fungi other than Aspergillus spp. recovered from the examined samples:

\begin{tabular}{|l|c|c|c|c|c|}
\hline \multirow{2}{*}{ Sample } & \multirow{2}{*}{$\begin{array}{c}\text { No. of } \\
\text { samples }\end{array}$} & \multicolumn{4}{|c|}{ Recovered fungi } \\
\cline { 3 - 6 } & & $\begin{array}{l}\text { Penicillium } \\
\text { spp. }\end{array}$ & \multicolumn{2}{c|}{ Mucor } \\
\cline { 3 - 6 } & & No. & $\%$ & No. & $\%$ \\
\hline $\begin{array}{l}\text { Poultry } \\
\text { ration }\end{array}$ & 90 & 29 & 32.2 & 26 & 28.9 \\
\hline $\begin{array}{l}\text { Ration } \\
\text { concentrates }\end{array}$ & 10 & 4 & 40 & 1 & 10 \\
\hline Yellow corn & 10 & 2 & 20 & 3 & 30 \\
\hline Soya bean & 10 & 2 & 20 & 4 & 40 \\
\hline Total & 120 & 37 & 30.8 & 34 & 28.3 \\
\hline
\end{tabular}

$\%$ was calculated according to the corresponding No samples. Incidence of Aspergillus species in poultry feed.

Data illustrated in Table (4) showed that out of 120 poultry feed samples, 125 Aspergillus species were recovered and were included in three species. Aspergillus flavus was the most frequent as 75 isolates $(62.5 \%)$, followed by $A$. niger $(n=31 ; 25.9 \%)$ and finally A. fumigatus $(n=19 ; 15.8 \%)$.

Table 4: Incidence of Aspergillus species in the examined samples.

\begin{tabular}{|l|c|c|c|}
\hline Aspergillus species & $\begin{array}{c}\text { Total No. } \\
\text { of } \\
\text { samples }\end{array}$ & No. & $\%$ \\
\hline Aspergillus flavus & & 75 & 62.5 \\
\hline Aspergillus niger & \multirow{2}{|c|}{\begin{tabular}{l} 
Aspergillus \\
\cline { 1 - 3 } \\
\cline { 3 - 4 } \\
fumigatus
\end{tabular}} & 19 & 25.9 \\
\hline
\end{tabular}

Incidence of different Aspergillus species in the different examined samples:

The results in Table (5) showed that 75 isolates (62.5\%) of Aspergillus flavus were recovered from the examined samples. The highest occurrence was recorded in poultry ration as 65 isolates/ 90 samples (72.2\%) followed by yellow corn $(5 / 10 ; 50 \%)$, ration concentrates $(3 / 10 ; 30 \%)$, and finally soya bean $(2 / 10$; $20 \%)$. 
Moreover, 31 A. niger isolates (25.9\%) were recovered from the examined samples. The highest occurrence was recorded in poultry ration as 25 isolates (27.8\%) followed by yellow corn $(n=3 ; 30 \%)$, ration concentrates $(n=2 ; 20 \%)$, and finally soya bean $(n=1$; 10\%). Regarding A. fumigatus, 19 isolates (15.8\%) were recovered from the examined samples. The highest occurrence was recorded in poultry ration as 15 isolates $(16.7 \%)$ followed by ration concentrates $(n=2$; $20 \%)$ and finally both yellow corn and soya bean $(n=1$; $10 \%$ for each).

Table 5: Incidence of different Aspergillus spp. in the different examined samples:

\begin{tabular}{|l|c|c|c|c|c|c|c|}
\hline \multirow{2}{*}{ Sample } & \multirow{2}{*}{$\begin{array}{c}\text { No. of } \\
\text { samples }\end{array}$} & \multicolumn{2}{c|}{ A. flavus } & \multicolumn{2}{c|}{ A. niger } & \multicolumn{2}{c|}{ A. fumigatus } \\
\cline { 3 - 8 } & & No. & $\%$ & No. & $\%$ & No. & $\%$ \\
\hline Poultry ration & 90 & 65 & 72.2 & 25 & 27.8 & 15 & 16.7 \\
\hline Ration concentrates & 10 & 3 & 30 & 2 & 20 & 2 & 20 \\
\hline Yellow corn & 10 & 5 & 50 & 3 & 30 & 1 & 10 \\
\hline Soya bean & 10 & 2 & 20 & 1 & 10 & 1 & 10 \\
\hline \multicolumn{1}{|c|}{ Total } & 120 & 75 & 62.5 & 31 & 25.9 & 19 & 15.8 \\
\hline
\end{tabular}

$\%$ was calculated according to the corresponding $31 \mathrm{~g}$ No. of samples.

\section{PCR confirmation for $A$. flavus isolates:}

PCR was applied on all Aspergillus flavus as a confirmatory diagnosis. The results revealed detection of $357 \mathrm{bp}$ Aspergillus $18 \mathrm{~S}$ rRNA gene of A. flavus in all tested isolates (Fig.1).

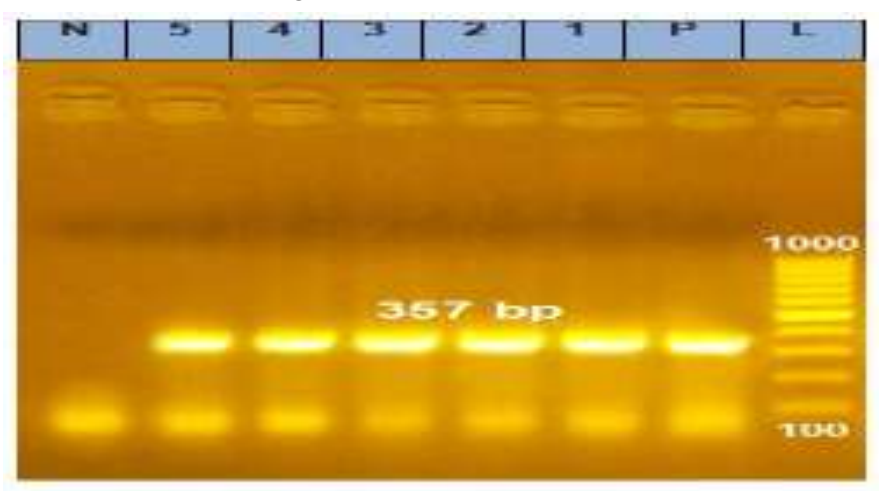

Fig. 1: PCR amplification of the $357 \mathrm{bp}$ fragment of Aspergillus $18 S$ rRNA gene from 5 A. flavus isolates (1-5), P. (control positive), N. (control negative).

Aflatoxin detection in the examined samples using Afla Test Fluorometer Method:

According to Table (6), mycotoxins analysis of the samples revealed that out of 75 examined samples, aflatoxin was detected in a total of 43 samples (57.3\%) while 32 samples (42.7\%) were negative for aflatoxin contamination.

Table 6: Incidence of aflatoxin production in poultry feed:

\begin{tabular}{|l|c|c|c|c|c|}
\hline \multirow{2}{*}{ Sample } & No. of & \multicolumn{2}{c|}{ Positive } & \multicolumn{2}{c|}{ Negative } \\
\cline { 3 - 6 } & samples & No. & $\%$ & No. & $\%$ \\
\hline Poultry ration & 65 & 39 & 60 & 21 & 40 \\
\hline Ration & 3 & 1 & 33.3 & 2 & 66.7 \\
concentrates & & & & & \\
\hline Yellow corn & 5 & 2 & 40 & 3 & 60 \\
\hline Soya bean & 2 & 1 & 50 & 1 & 50 \\
\hline \multicolumn{1}{|c|}{ Total } & 75 & 43 & 57.3 & 32 & 42.7 \\
\hline
\end{tabular}

Amount of toxin in positive samples range from $25-50 \mathrm{ppb}$.

\section{DISCUSSION}

Mycotoxins are considered unavoidable contaminants in foods and feeding stuff because agronomical technology has not yet advanced to the stage at which preharvest infection of susceptible crops by fungi can be eliminated. These Feeds in storage conditions with more than $12-15 \%$ moisture suitable to grow fungi. Because aerobically growth of most molds, increasing of moisture concentrations can eliminate air and prevent mold growth. (Ghaemmaghami et al., 2016).

Feed stuffs are liable to be contaminated by molds and or fungi producing toxins which make the food nasty, unpleasant and toxic. Feed is considered the major cost of poultry production that lies between 65 and $75 \%$., therefore, any effect on the feed leads to change on the performance of broilers and layers .The storage conditions are necessary to safe feed, so weather extremes unsuitable storage practices and improper feeding conditions can cause feed - fungal contamination that increase mycotoxins production. (Nkukwana et al., 2018). So it is desirable from time to time to examine these stuff periodically either from the superficial looking and/or laboratory examination for the presence of any toxic materials.

Results presented in Table (3) showed the different fungi other than Aspergillus spp. recovered from 120 poultry feed samples. The most prevalent genus was Penicillium which appeared in 37 samples (30.8\%) out of 120 examined samples and Mucor spp. Appeared in 34 samples (28.3\%) out of 120 examined samples. These results agree with those of Abd El Hamid et al., (1989) who isolated Penicillium spp. At a rate of $31 \%$ out of 73 poultry diets, and disagree with Dalcero et al., (1997) who reported that the 


\section{Detection of Aflatoxigenic Fungi in Poultry Feed}

Penicillium spp. Occurred in high level in poultry feed reaching $87 \%$.

Data illustrated in Table (4) showed the incidence of Aspergillus species in poultry feed. Out of 120 poultry feed samples, 125 Aspergillus species representing 3 species. Aspergillus flavus was the most frequent $(62.5 \%)$, followed by A. niger $(25.9 \%)$ and finally $A$. fumigatus $(15.8 \%)$. This indicates that Aspergillus flavus is the most prevalent isolated species. These results agree with those of Magnoli $\boldsymbol{e t}$ al., (1998) who recorded that, Aspergillus flavus is the most prevalent isolated species 57 (32\%) recovered from poultry feed samples, Connole et al., (1981) who reported that $200(56.33 \%)$ were Aspergillus flavus isolated from 355 feed samples, Kumari et al., (1995) that reported Aspergillus flavus was isolated from 90 (90\%) samples and Jand and Singh (1995) screened 332 samples of poultry feed and found that 316 (95.1\%) of samples were positive for the presence of fungi. Aspergillus flavus was the predominant fungus with the percentage of $47.4 \%$ while Aspergillus niger was (6\%). Aliyu et al.,(2016) reported that, 125 samples of commercial mixed poultry feeds; Aspergillus flavus was isolated from 125.Viegas et al., (2017) examined 100 samples from different sources (poultry farms and feed manufacturers). Aspergillus flavus was isolated from 90 . This result disagree with Le Bars,(1982) and Bragulant et al., (1995) who reported that Aspergillus flavus present in feed samples a low level.

The results illustrated in Table (5) presented the incidence of different Aspergillus species in the different examined samples. Regarding A.s flavus, the highest prevalence of contamination was recorded in poultry ration samples $(72.2 \%)$ followed by yellow corn $(50 \%)$, ration concentrates $(30 \%)$, and finally soya bean $(20 \%)$. The high level of Aspergillus flavus in Poultry ration maybe due to unsuitable storage conditions or maybe that the feeding stuffs were used as raw materials for the preparation of compound feed (poultry ration) and these feed stuffs were contaminated with fungi. These results agree with Abou El- Magd (1997) who reported that poultry ration was highly contaminated with Aspergillus flavus (10\%) followed by ration concentrates (9\%), yellow corn $(8.7 \%)$, and soya bean $(1.5 \%)$. Meanwhile, $A$. niger and A. fumigatus were isolated at a high level in poultry ration followed by ration concentrates, then yellow corn and soya bean. This result agreed with Abou El- Magd (1997) who reported that poultry ration was highly contaminated with Aspergillus spp.

PCR technique was applied for confirmatory diagnosis of all Aspergillus flavus using Aspergillus
$18 S$ rRNA gene of A. flavus. The results revealed detection of the gene in all tested isolates (Fig.1).

Data illustrated in Table (6) represented the mycotoxins analysis of the examined samples. A total of $43 / 75$ samples $(57.3 \%)$ were aflatoxin contaminated meanwhile $32 / 75$ samples $(42.7 \%$ ) were negative for aflatoxin contamination. This result agreed with Dalcero et al., (1997) who reported that aflatoxin was the predominant toxin detected in poultry feed samples, and Natour et al., (1985) who reported that aflatoxins were found in $63.9 \%$ of poultry feed samples due to unsuitable storage condition but in our studies the high level of aflatoxins is due to the samples have been collected from farms that had disease problems so the samples are suspected to be mycotoxin contaminated. Viegas et al., (2017) found that 23 (25.55\%) samples from 100 examined samples were toxigenic.

\section{CONCLUSION}

The most predominant Aspergillus isolates from poultry feed was A. flavus About $57.3 \%$ of $A$. flavus isolates produced aflatoxins. These results concluded that the potential exists for the production of aflatoxins by the Aspergillus flavus.

\section{Declaration of Conflicting Interests}

The authors revealed that there was no potential conflicts of interest.

\section{REFERENCES}

AOAC, 1990. Official methods of analysis ( $15^{\text {th }}$ ed.) Artington, VA, Association of official analytical chemists).

ALIYU, R. M., ABUBAKAR, M. B., YAKUBU, Y., KASARAWA, A. B., LAWAL, N., BELLO, M. B., \& FARDAMI, A. Y., 2016. Prevalence of potential toxigenic Aspergillus species isolated from poultry feeds in Sokoto metropolis. Sokoto Journal of Veterinary Sciences, 14(1), 39-44.

NKUKWANA, T. T., 2018. Global poultry production: Current impact and future outlook on the South African poultry industry. South African Journal of Animal Science, 48(5), 869-884.

GHAEMMAGHAMI, S. S., MODIRSANEII, M., KHOSRAVI, A. R., AND RAZZAGHIABYANEH, M., 2016. Study on mycoflora of poultry feed ingredients and finished feed in Iran. Iranian journal of microbiology, 8(1), 47.

COLlee, J. G.; MARMIOM, B. P.; FRASER, A. G. AND ANTHONY, S., 1989. Practical Microbiology, $12^{\text {th }} \mathrm{ED}$.

DALCERO, A.; MAGNOLI, C.; LUNA, M.; ANCASI, G.; REYNOSO, M. M.; CHIACCHIERA, S.; MIAZZO, R. AND PALACIO, G.,1998. Mycoflora and naturally occurring mycotoxins in poultry feeds in Argentina. Mycopathologia, 141(1): 37-43.

GHADEER, A.O. AND AL-DELAMIY, K.S., 2012. Aflatoxin B1 production by Aspergillus flavus in 
different media and containers and the antifungal activity of garlic and black cumin. Research Journal of Engineering and Applied Science, 1(2): 117-121.

HABIB, M.A.; ABDU, P.; KWANASHIE, C.N.; KABIR, J. AND NEGEDU, A., 2015. Isolation and identification of Aspergillus species from poultry feeds in Kaduna State, Nigeria. Microbiology Research International, 3(2): 27-32.

HANSEN T.J., 1990. Affinity column cleanup and direct fluorescence measurement of Aflatoxin. Journal of food protection, 53 (1) : 75-77.

HARUNA, M.; DANGORA, D.B.; KHAN, A.U.; BATAGARAWA, U.S.B. AND IBRAHIM, H., 2017. Incidence of Fungal Flora and Aflatoxin in Some Spices Sold in Central Market, Funtua, Nigeria. MYU Journal of Microbiology Research. 2(1): 47-53.

HUSSAIN, I, ANWAR,J, 2008. Food Control, A study on contamination of aflatoxin M1 in raw milk in the Punjab province of Pakistan, 19: 393-395.

LEREAU, M.; GOUAS, D.; VILLAR, S.; BESARATINIA, A.; HAUTEFEUILLE, A.; BERTHILLON, P.; MARTEL- PLANCHE, G.; NOGUEIRA DA COSTA, A.; ORTIZ-CUARAN, S.; HANTZ, O.; PFEIFER, G.P.; HAINAUT, P. AND CHEMIN, I., 2012. Interactions between hepatitis B virus and aflatoxin B1: Effects on p53 induction in heparg cells. Journal of General Virology. 93: 640-650.

LI, R ET A.L., 2014. Food Control, Occurrence of four mycotoxins in Cetreal and oil products in the Yangtze Delta region of China and their food safety risks, 35: 117-122.

LIU, Y. AND WU, F., 2010. Global burden of aflatoxin induced hepatocellular carcinoma: A risk assessment. Environmental Health Perspectives, 118: 818-824.

MACIOROWSKI, K.G.; HERRERA, P.; JONES, F.T.; PILLAI, S.D. AND RICKE, S.C., 2007. Effects on poultry and livestock of feed contamination with bacteria and fungi. Animal Feed Science and Technology. 133(1- 2): 109-136.

MAGNOLI, A.P.; MONGE, M.P.; MIAZZO, R.D.; CAVAGLIERI, L.R.; MAGNOLI, C.E.; MERKIS, C.I, ET A.L.,2011. Effect of low levels of aflatoxin B1 on performance, biochemical parameters, and aflatoxin B1 in broiler liver tissues in the presence of monensin and sodium bentonite. Poultry Science. 90: 48-58.

MONBALIU, S.; VAN POUCKE, C.; DETAVERNIER, C.; DUMOULIN, F.; VAN DE VELDE, M.; SCHOETERS, E.; VAN DYCK, S.; AVERKIEVA, O.; VAN PETEGHEM, C. AND DE SAEGER, S., 2010. Occurrence of mycotoxins in feed as analyzed by a multi- mycotoxin LC-MS/MS method. Journal of Agriculture and Food Chemistry, 58: 66-71.

MONSON, M.S.; SETTLAGE, R.E.; MCMAHOON, K.W.; MENDOZA, K.M.; RAWAL, S.; ELNEZAMI, H.S.; COULOMBE, R.A. AND REED, K.M., 2014. Response of the hepatic transcriptone to aflatoxin B1 in domestic turkey (Meleagris gallopavo). PLosONE. 9(6): e100930.
MOSTAFA, A; ARMIN, A.; HAMID, P. AND REZA, A.M., 2012. Review paper: Rapid detection methods for analysis of fungi and mycotoxins in Agriculture products. Research Journal of Recent Sciences. 1(7): 90-98.

RIPPON, J. W., 1988. Medical Mycology-The Pathogenic Fungi and the Pathogenic Actinomycetes ( $3^{\text {rd }}$ Ed.).

SALIM, A.B.; ZOHAIR, A.; HEGAZY, A.E.S. AND SAID, A., 2011. Effect of some strains of probiotic bacteria against toxicity induced by aflatoxins. Journal of American Science. 7(1): 772-783.

SAMBROOK, J.; FRITSCGH, E.F.;AND MENTIATES, 1989 Molecular cloning. A laboratory manual. Vol !., Cold spring Harbor Laboratotry press, New York.

TOLA, M. AND KEBEDE, B., 2016. Occurrence, importance and control of mycotoxins: A review. Cogent Food and Agriculture. 2: 1-12.

VARGA, J.; FRISVAD, J.C. AND SAMSON, R.A., 2011. Two new aflatoxin producing species and an overview of Aspergillus section Flavi. Studies in Mycology, 69(1): 57-80.

VIEGAS, C., FARIA, T., CAETANO, L. A., CAROLINO, E., GOMES, A. Q., \& VIEGAS, S., 2017. Aspergillus spp. prevalence in different Portuguese occupational environments: What is the real scenario in high load settings?. Journal of occupational and environmental hygiene, 14(10), 771-785.

WHO 2002. World Health organization. Department of communicable diseases surveillance and response.

WHO. 2006. Mycotoxins in African foods: Implications to Food Safety and Health. AFRO Food Safety Newsletter. 2: 1-10.

WHO. 2008. World Health Statistics. WHO Press, Geneva, https://www. Who. Int/Whosis/Whostat/2008/en/

XU, L.; ZHANG, Z.; ZHANG, Q.; ZHANG, W.; YU, L.; WANG, D. AND LI, P.. 2000. An On-Site Simultaneous Semi-Quantification of Aflatoxin B1, Zearalenone, and T-2 Toxin in Maize- and CerealBased Feed via Multicolor Immuno-chromatographic Assay. Toxins, 10(2): 87.

YAMAKAMI, Y.; HASHIMOTO, A.; TOKIMATSU, I. AND NASU, M., 1996. PCR Detection of DNA Specific for Aspergillus Species in Serum of Patients with Invasive Aspergillosis.

How to cite this article:

Walid H. Hassan, Salem R. Mostafa, Hossam A. Khalil and Ahmed H. Abed, 2021. Detection of Aflatoxigenic Fungi in Poultry Feed. Journal of Applied Veterinary Sciences, 6 (2): $91-97$. DOI:https://dx.doi.org/10.21608/javs.2021.68213.1074 